\title{
Prevalence and risk factors for patient-reported joint pain among patients with HIV/Hepatitis C coinfection, Hepatitis C monoinfection, and HIV monoinfection
}

\author{
Alexis Ogdie ${ }^{1 * \dagger}$, Wyki Gina Pang ${ }^{2 \dagger}$, Kimberly A Forde ${ }^{3}$, Bhangle D Samir ${ }^{4}$, Lakeisha Mulugeta ${ }^{5}$, Kyong-Mi Chang ${ }^{6}$, \\ David E Kaplan ${ }^{6}$, Valerianna K Amorosa”, Jay R Kostman", Rajender K Reddy ${ }^{8}$, Ralph H Schumacher ${ }^{9}$ \\ and Vincent Lo Re $\mid I^{10}$
}

\begin{abstract}
Background: To determine the prevalence of patient-reported joint pain among patients with human immunodeficiency virus (HIV)/chronic hepatitis C virus (HCV) coinfection, chronic HCV monoinfection, and HIV monoinfection followed in hepatology and infectious disease outpatient practices.

Methods: Standardized interviews were performed among 79 HIV/HCV-coinfected, 93 HCV-monoinfected, and 30 HIV-monoinfected patients in a cross-sectional study within hepatology and infectious disease clinics at three centers. The Multi-Dimensional Health Assessment Questionnaire was used to ascertain joint pain and associated symptoms. Information on potential risk factors for joint pain was obtained during the interview and by chart review. Logistic regression was used to determine adjusted odds ratios (aORs) with 95\% confidence intervals (Cls) of joint pain associated with risk factors of interest among chronic HCV-infected and HIV-infected patients.
\end{abstract}

Results: Joint pain was more commonly reported in HCV-monoinfected than HIV/HCV-coinfected (71\% versus 56\%; $p=0.038$ ) and HIV-monoinfected (71\% versus 50\%; $p=0.035$ ) patients. A previous diagnosis of arthritis and current smoking were risk factors for joint pain among HCV-infected patients (arthritis: aOR, 4.25; 95\% Cl, 1.84-9.81; smoking: aOR, 5.02; 95\% Cl, 2.15-11.74) and HIV-infected (arthritis: aOR, 5.36; 95\% Cl, 2.01-14.25; smoking: aOR, 6.07; 95\% Cl, 2.30-16.00) patients.

Conclusion: Patient-reported joint pain was prevalent among all three groups, but more common among chronic HCV-monoinfected than either HIV/HCV-coinfected or HIV-monoinfected patients. A prior diagnosis of arthritis and current smoking were risk factors for patient-reported joint pain among both HCV-infected and HIV-infected patients.

Keywords: Hepatitis c, HIV, Arthralgia, Epidemiology

\section{Background}

Hepatitis $\mathrm{C}$ virus ( $\mathrm{HCV}$ ) infection is the most common blood-borne infection in the United States and is a leading cause of advanced liver disease. Over 4 million people in the U.S. and more than 170 million people worldwide have been infected with HCV infection [1,2]. Many extrahepatic

\footnotetext{
*Correspondence: Alexis.ogdie@uphs.upenn.edu

${ }^{\dagger}$ Equal contributors

'Division of Rheumatology, Center for Clinical Epidemiology and Biostatistics, Perelman School of Medicine at the University of Pennsylvania, Penn Tower Room 1407, 1 Convention Ave, Philadelphia PA 19104, USA

Full list of author information is available at the end of the article
}

manifestations have been associated with chronic $\mathrm{HCV}$ infection, including dermatologic, neurologic, renal, and rheumatic disorders [3-10]. While chronic HCV-induced inflammation is generally thought to be a key contributor to these manifestations, the mechanisms by which they occur remain unclear [11].

Rheumatologists are frequently faced with managing chronic HCV-infected patients with joint pain. However, few published studies have evaluated: 1) the prevalence of patient-reported joint pain among patients with chronic HCV in the U.S., 2) how joint symptoms among patients with chronic $\mathrm{HCV}$ affect quality of life and

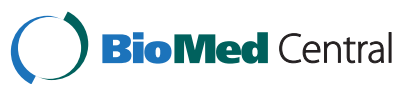

(c) 2015 Ogdie et al.; licensee BioMed Central. This is an Open Access article distributed under the terms of the Creative Commons Attribution License (http://creativecommons.org/licenses/by/4.0), which permits unrestricted use, distribution, and reproduction in any medium, provided the original work is properly credited. The Creative Commons Public Domain Dedication waiver (http://creativecommons.org/publicdomain/zero/1.0/) applies to the data made available in this article, unless otherwise stated. 
functional ability, or 3) whether coinfection with chronic $\mathrm{HCV}$ and human immunodeficiency virus (HIV) affects the prevalence of patient-reported joint pain. HIV infection has also been associated with rheumatic conditions, including reactive arthritis, psoriatic arthritis, and arthralgias and myalgias without identifiable inflammatory disease [12]. While HIV coinfection accelerates chronic HCV-related liver fibrosis progression to cirrhosis and hepatic decompensation, [13-15] the role of HIV/HCV coinfection on the development of joint pain remains unknown.

The primary objective of this study was to determine the prevalence of patient-reported joint pain (arthralgias) among patients with HIV/chronic HCV coinfection, chronic HCV monoinfection, and HIV monoinfection followed in hepatology and infectious disease clinics. We hypothesized that there would be a higher prevalence of arthralgias in $\mathrm{HIV} / \mathrm{HCV}$-coinfected patients compared to those who have chronic $\mathrm{HCV}$ or HIV alone. Our second objective was to examine potential risk factors for patient-reported joint pain among chronic $\mathrm{HCV}$-infected (i.e., $\mathrm{HIV} / \mathrm{HCV}$-coinfected and HCV-monoinfected) and HIV-infected (i.e., HIV/HCVcoinfected and HIV-monoinfected) patients.

\section{Methods}

\section{Study design and setting}

We performed a cross-sectional study among patients with HIV/chronic HCV coinfection, chronic $\mathrm{HCV}$ monoinfection, and HIV monoinfection. Consecutive patients with chronic $\mathrm{HCV}$ and/or HIV infections were recruited in hepatology and infectious disease clinics at three tertiary care medical centers within Philadelphia (Penn Presbyterian Medical Center [PPMC], Philadelphia Veterans Affairs Medical Center [PVAMC], and the Hospital of the University of Pennsylvania [HUP]). The PPMC infectious disease outpatient practice specializes in viral hepatitis care; hepatologists and infectious disease physicians see patients concurrently in the HUP viral hepatitis clinic; and the PVAMC outpatient infectious disease and hepatology clinics are located within the same practice space. Patients were enrolled between November 2008 and March 2012.

\section{Study patients}

Participants were eligible for inclusion if they were between 18 and 80 years of age and had documentation of HIV (HIV antibody- or RNA-positive) and/or chronic HCV infection (HCV RNA-positive) in their medical record. Exclusion criteria included the inability to either speak or understand English or to provide informed consent.

\section{Measurements}

Participants were asked to complete an intervieweradministered questionnaire that ascertained the presence or absence of patient-reported joint pain over the one week prior to the study visit, the duration of joint pain, the joints affected, and previous diagnoses of joint disorders or arthritis. Among patients reporting joint pain, an interviewer administered the Multi-Dimensional Health Assessment Questionnaire (MD-HAQ, version R780NP2) [16] given the highly varied reading skills and medical literacy in the patient population surveyed. Interviews were standardized among the four questionnaire administrators (WGP, LM, SB, and AO). The MDHAQ includes a physical function score (range, 0 to 10), emotional function score (0 to 9.9), a pain score (range, 0 to 10), global health assessment (range, 0 to 10), fatigue scale (range, 0 to 10), ratings of painful joints, responses to a review of systems, and basic demographics (e.g. age, sex, height, weight, education, employment status and occupation). The MD-HAQ scores for physical function, pain, and global health status can be combined into a composite index known as the Routine Assessment of Patient Index Data (RAPID3; range, 0 to 30). In rheumatoid arthritis, a RAPID3 score of $>12$ (on a scale from 0-30) indicates high disease activity, a score of 6.01-12 suggests moderate disease activity, a score of 3.01-6 suggests lower disease activity, and scores $\leq 3$ indicate disease remission [17]. The MD-HAQ also includes three questions on "emotional function" (depression, anxiety, sleep disturbance), each ranging from 0 to 3.3 in 1.1 increments. These three scores were summed to result in an "emotional function" score ranging from 0-9.9. The MD-HAQ includes a review of systems, including symptoms such as dry mouth, dry eyes, numbness and tingling in the extremities, myalgias, and morning stiffness (a total of 60 symptoms are included in the review of systems) and a visual analog scale for fatigue. The MD-HAQ and RAPID3 have been validated in patients with rheumatoid arthritis and have previously been used in rheumatologic epidemiological studies [18-20]. Additionally, the MDHAQ has been used in clinical practice to evaluate many different diseases, including osteoarthritis and fibromyalgia [21,22].

Medical records were also reviewed to abstract age at study visit, sex, race, height and body weight, analgesic medication use (e.g., use of narcotic analgesics, nonsteroidal anti-inflammatory drugs, acetaminophen, or gabapentin), medical comorbidities (i.e., diabetes mellitus, hypertension, congestive heart failure, coronary artery disease, hyperlipidemia, obstructive sleep apnea, chronic kidney disease, psoriasis, inflammatory bowel disease, lymphoma, thyroid disease, history of arthritis, anxiety disorder, depression), HIV-related data (CD4 cell count, HIV RNA level, use of antiretroviral therapy), HCV-related data (HCV genotype, HCV RNA level, current or prior interferon-based HCV therapy; hepatic decompensation diagnoses [ascites, spontaneous bacterial 
peritonitis, esophageal variceal hemorrhage, hepatic encephalopathy]; hepatocellular carcinoma), relevant social history (history of smoking, alcohol use, intravenous drug use, homelessness, incarceration, blood transfusion), and most recently recorded laboratory results of total bilirubin, asparate aminotransferase (AST), alanine aminotransferase (ALT), albumin, international normalized ratio (INR), white blood cell count, hemoglobin, and platelet count.

\section{Data analysis}

The prevalence of joint pain was determined and expressed as a point estimate (percent) and 95\% confidence interval (CI) within each group. Descriptive statistics were used to compare characteristics between groups (HIV/HCV-coinfected, HCV-monoinfected, and HIVmonoinfected). Differences between groups were determined using Chi-square or Fisher's exact tests, when appropriate, for categorical data, and Wilcoxon ranksum tests for continuous data. Logistic regression was used to determine adjusted odds ratios (aORs) with 95\% CIs of joint pain associated with risk factors of interest among chronic $\mathrm{HCV}$-infected (i.e., HIV/HCV-coinfected and HCV-monoinfected) and HIV-infected (i.e., $\mathrm{HIV} / \mathrm{HCV}$-coinfected and HIV-monoinfected) patients. Variables evaluated as risk factors for joint pain included age, sex, race, history of arthritis, history of anxiety disorder or depression, obesity (body mass index $\left.[\mathrm{BMI}]>30 \mathrm{~kg} / \mathrm{m}^{2}\right), \mathrm{AST}, \mathrm{ALT}$, current $\mathrm{HCV}$ therapy, use of analgesic medications, HCV genotype (in chronic $\mathrm{HCV}$-infected patients only), and CD4 cell count (in HIV-infected patients only). Since HCV treatment has been associated with arthralgias, we performed a sensitivity analysis in which we excluded patients currently utilizing this therapy and repeated the analyses above.

\section{Ethical approval}

This study was approved by the Institutional Review Boards of the University of Pennsylvania and PVAMC. Written informed consent was obtained from all patients participating in the study.

\section{Results}

A total of 202 participants were enrolled (79 HIV/HCVcoinfected; 93 HCV-monoinfected; 30 HIV-monoinfected). The characteristics of each group are presented in Table 1. Among the three groups, age and sex distributions were similar. Over half of participants were black (AfricanAmerican or Caribbean-American decent). HCV genotype 1 was the most common genotype among chronic $\mathrm{HCV}$ patients. Median HCV RNA levels were higher in coinfected than HCV-monoinfected patients. Few chronic $\mathrm{HCV}$-infected patients were currently receiving $\mathrm{HCV}$ therapy but approximately half previously received $\mathrm{HCV}$ treatment. Three patients reported a prior diagnosis of rheumatoid arthritis (2 with HCV monoinfection, 1 with $\mathrm{HCV} / \mathrm{HIV}$ coinfection), one with systemic lupus erythematosus (HCV-monoinfected), one with ankylosing spondylitis (HIV-monoinfected), and one with inflammatory arthritis not otherwise specified (HCV-monoinfected). Use of analgesic medications was similar among the groups. The mean BMI was significantly lower in coinfected and HIV-monoinfected patients. Liver aminotransferase levels were higher and platelet counts were lower in coinfected and HCV-monoinfected patients. Other laboratory values did not significantly differ between the groups (Additional file 1: Table S1).

Over half of the patients reporting joint pain also selfreported depression and anxiety on the MD-HAQ. Depression was reported by $50 \%$ of $\mathrm{HCV}$-monoinfected, $80 \%$ of HIV-monoinfected, and $64 \% \mathrm{HIV} / \mathrm{HCV}$-coinfected patients. Similarly, anxiety was reported by $51 \%$ of HCV-monoinfected, $67 \%$ of HIV-monoinfected, and $77 \%$ of coinfected patients.

Joint pain was more commonly reported among HCVmonoinfected than coinfected $(71 \%$ versus $56 \%$; $\mathrm{p}=$ 0.038 ) or HIV-monoinfected patients (71\% versus 50\%; $\mathrm{p}=0.035$ ). After adjustment for age and sex, HCVmonoinfected patients were 1.9 -fold more likely to report joint pain compared to coinfected patients (aOR, 1.94 ; $95 \% \mathrm{CI}, 1.02-3.67$ ) and 2.4-fold more likely to report arthralgias compared to HIV-monoinfected patients (aOR, 2.43; 95\% CI, 1.03-5.72). No differences in the prevalence of joint pain were observed between coinfected and HIV-monoinfected patients (56\% versus 50\%; $\mathrm{p}=0.59)$. HIV/HCV coinfection remained unassociated with arthralgias compared to HIV monoinfection after adjustment for age and sex (aOR, 1.25; 95\% CI, 0.542.92). A sensitivity analysis excluding chronic HCVinfected patients currently on HCV therapy $(n=22)$ revealed similar proportions of chronic $\mathrm{HCV}$-infected persons reporting joint pain (data not shown).

Among all three groups, fingers, knees, and back were the most frequently cited areas of joint pain (Figure 1). The distribution of painful joints was similar among the groups, although HCV-monoinfected patients more commonly reported finger pain compared to coinfected (41\% versus $27 \% ; \mathrm{p}=0.035)$ and HIV-monoinfected $(41 \%$ versus $23 \% ; \mathrm{p}=0.067$ ) patients.

MD-HAQ results among participants reporting joint pain are reported in Table 2. The mean (SD) MD-HAQ among participants reporting joint pain was 6.0 (2.77), and the mean (SD) RAPID3 was 12.9 (5.46). The RAPID3 components did not significantly differ by HIV/HCV status. The mean (SD) duration of morning stiffness among participants reporting joint pain was 57.3 (158.1) minutes. Symptoms of dry mouth, ascertained by the MD-HAQ, were less commonly reported among HIV-monoinfected 
Table 1 Baseline characteristics of human immunodeficiency virus (HIV)/chronic hepatitis C virus (HCV)-coinfected, chronic HCV-monoinfected, and HIV-monoinfected participants

\begin{tabular}{|c|c|c|c|c|c|}
\hline & HCV/HIV- & HCV- & HIV- & P-value* & \\
\hline & Coinfected & Monoinfected & Monoinfected & $\mathrm{HCV} / \mathrm{HIV}$ & $\mathrm{HCV} / \mathrm{HI}$ \\
\hline & $N=79$ & $N=93$ & $N=30$ & vs HCV & V vs HIV \\
\hline Site $(n, \%)$ & & & & $<0.001$ & $<0.001$ \\
\hline HUP & $2(3 \%)$ & $35(38 \%)$ & $0(0 \%)$ & & \\
\hline PPMC & 35 (44\%) & $20(22 \%)$ & $1(3 \%)$ & & \\
\hline PVAMC & 42 (53\%) & $38(41 \%)$ & $29(97 \%)$ & & \\
\hline Age (Median, IQR) & $55(43-64)$ & $57.5(53.5-61)$ & $54(51-60)$ & $0.04^{\dagger}$ & $\mathrm{NS}^{+}$ \\
\hline $\operatorname{Sex}(n, \%)$ & & & & NS & NS \\
\hline Male & $68(86 \%)$ & 77 (83\%) & $28(93 \%)$ & & \\
\hline Female & $11(14 \%)$ & $16(17 \%)$ & $2(7 \%)$ & & \\
\hline Race $(n, \%)$ & & & & 0.001 & NS \\
\hline Caucasian & $9(11 \%)$ & $35(38 \%)$ & $5(17 \%)$ & & \\
\hline Black & $64(81 \%)$ & $50(54 \%)$ & $24(80 \%)$ & & \\
\hline Hispanic & $4(5 \%)$ & $3(3 \%)$ & $0(0 \%)$ & & \\
\hline Other & $2(3 \%)$ & $2(2 \%)$ & $1(3 \%)$ & & \\
\hline BMI $\left(\mathrm{kg} / \mathrm{m}^{2}\right)$ & 25.0 & 29.2 & 27.2 & $<0.001^{\dagger}$ & $0.05^{\dagger}$ \\
\hline Median (IQR) & $(22.5-29.0)$ & $(25.5-33.2)$ & $(25.0-33.2)$ & & \\
\hline Current smoker $(n, \%)$ & $29(37 \%)$ & $37(40 \%)$ & $9(30 \%)$ & NS & NS \\
\hline HCV Treatment $(\mathrm{n}, \%)$ & & & & 0.01 & N/A \\
\hline Current & $4(5 \%)$ & $17(18 \%)$ & $0(0 \%)$ & & \\
\hline Past & $22(28 \%)$ & $31(33 \%)$ & $0(0 \%)$ & & \\
\hline Never & $53(67 \%)$ & 45 (48\%) & $30(100 \%)$ & & \\
\hline HCV Genotype (n, \%) & & & & NS & N/A \\
\hline $1(A$ or $B)$ & $70(89 \%)$ & $60(65 \%)$ & $0(0 \%)$ & & \\
\hline 2 & $1(1 \%)$ & $5(5 \%)$ & $0(0 \%)$ & & \\
\hline 3 & $1(1 \%)$ & $4(4 \%)$ & $0(0 \%)$ & & \\
\hline HCV RNA (IU/mL) & 1.37 & 0.62 & N/A & $0.02^{+}$ & N/A \\
\hline Median in million (IQR) & $(0.44-4.63)$ & $(0.03-2.70)$ & & & \\
\hline CD4 count $\left(\right.$ cells $\left./ \mathrm{mm}^{3}\right)$ & 474 & $\mathrm{~N} / \mathrm{A}$ & 480 & N/A & $\mathrm{NS}^{+}$ \\
\hline Median (IQR) & $(358-666)$ & & $(295-673)$ & & \\
\hline Antiretroviral & $67(85 \%)$ & $0(\%)$ & $26(87 \%)$ & N/A & NS \\
\hline therapy $(n, \%)$ & & & & & \\
\hline Previous arthritis diagnosis ${ }^{\ddagger}(n, \%)$ & $37(40 \%)$ & $28(35 \%)$ & $8(27 \%)$ & NS & NS \\
\hline Analgesic medication use ( $\mathrm{n}, \%)$ & & & & NS & NS \\
\hline Any & $41(52 \%)$ & 49 (53\%) & $20(67 \%)$ & & \\
\hline Opiate & $15(19 \%)$ & $15(16 \%)$ & $4(13 \%)$ & & \\
\hline Gabapentin & $17(22 \%)$ & $11(12 \%)$ & $8(27 \%)$ & & \\
\hline NSAIDs & $21(27 \%)$ & $23(25 \%)$ & $10(33 \%)$ & & \\
\hline Tylenol & 10 (13\%) & 18 (19\%) & $9(30 \%)$ & & \\
\hline
\end{tabular}

Abbreviations: HUP $=$ Hospital of University of Pennsylvania, PPMC = Penn Presbyterian Medical Center, PVAMC = Philadelphia Veterans Affairs Medical Center, $\mathrm{BMI}=$ body mass index, NS = Not significant $(\mathrm{p}>0.05), \mathrm{N} / \mathrm{A}=$ Not Applicable.

FPrevious arthritis diagnosis included rheumatoid arthritis $(\mathrm{N}=4)$, osteoarthritis $(\mathrm{N}=46)$, ankylosing spondylitis $(\mathrm{N}=1)$, systemic lupus erythematosus ( $\mathrm{N}=1)$, and patient reported "arthritis" but unknown type $(\mathrm{N}=22)$. One patient carried more than one diagnosis.

${ }^{t}$ Wilcoxan-rank sum test, remainder of the $\mathrm{p}$-values were calculated using the chi2 test. 


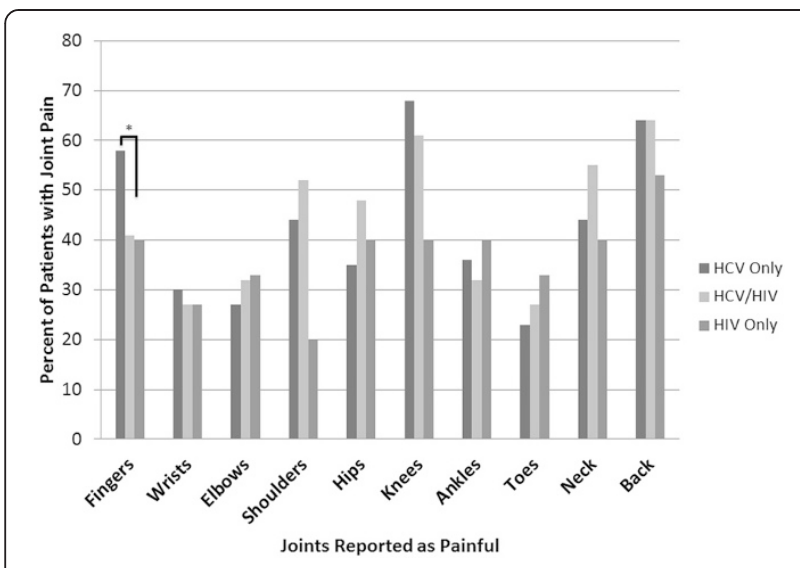

Figure 1 Sites of joint pain, by human immunodeficiency virus (HIV) and chronic hepatitis C virus (HCV) Status (\%).The distribution of painful joints was similar among the groups, although HCVmonoinfected patients more commonly reported finger pain compared to coinfected ( $41 \%$ versus $27 \% ; p=0.035)$ and HIVmonoinfected ( $41 \%$ versus $23 \% ; p=0.067$ ) patients. The $p$-values for the remainder of the comparisons were $>0.05$.

than coinfected (20\% versus $45 \% ; \mathrm{p}=0.08)$ or $\mathrm{HCV}$ monoinfected ( $20 \%$ versus $48 \%$; $\mathrm{p}=0.04)$ patients. Coinfected participants were more likely to report myalgias than HCV-monoinfected (43\% versus $27 \%$; $\mathrm{p}=0.06$ ) or HIV-monoinfected ( $43 \%$ versus $7 \% ; \mathrm{p}=0.01$ ) persons. Additionally, patients with $\mathrm{HIV} / \mathrm{HCV}$ coinfection were more likely to report numbness or tingling of the extremities compared to patients with HCV monoinfection $(41 \%$ versus $27 \% ; \mathrm{p}=0.14$ ) or HIV monoinfection ( $41 \%$ versus $7 \% ; \mathrm{p}=0.01$ ).

A previous diagnosis of arthritis (aOR, 4.25; 95\% CI, 1.84-9.81) and current smoking (aOR, 5.02; 95\% CI, 2.15-11.74) were risk factors for self-reported joint pain among chronic HCV-infected patients (Table 3). These associations remained when persons currently receiving $\mathrm{HCV}$ therapy were excluded (data not shown). Among HIV-infected patients, current smoking (aOR, 6.07; 95\% CI, 2.30-16.00) and a previous diagnosis of arthritis (aOR, 5.36; 95\% CI, 2.01-14.25) were also associated with arthralgias.

\section{Discussion}

This cross-sectional study demonstrated that joint pain was commonly reported and associated with diminished functional status and emotional well-being among patients with chronic HCV and/or HIV infection. The prevalence of joint pain was significantly higher among $\mathrm{HCV}$-monoinfected than HIV/HCV-coinfected and HIVmonoinfected patients. Over two-thirds of patients with chronic HCV monoinfection reported joint pain, while approximately half of coinfected and HIV-monoinfected patients reported arthralgias.
Our study extends results of prior cross-sectional analyses, which have reported that $67-81 \%$ of chronic $\mathrm{HCV}$-infected patients complain of musculoskeletal pain [23,24]. Tsui et al. [25] found that HIV/HCV coinfection was more commonly associated with musculoskeletal pain compared to HIV-monoinfection (aOR, 1.45; 95\% CI, 1.06-1.97), and adjusting for inflammatory cytokine levels and depression did not change these results. Consistent with our results, Cacoub et al. [26] found that HIV/HCV-coinfected patients less commonly had arthralgias compared with HCV-monoinfected patients (5\% versus $29 \%$ ). However, none of these studies directly compared joint complaints among $\mathrm{HIV} / \mathrm{HCV}$ coinfected, HCV-monoinfected, and HIV-monoinfected patients, as was performed in this study.

The etiology of joint pain in chronic HCV infection remains unclear. Immune activation, direct viral particle deposition in the synovium, and the high prevalence of concomitant mood disorders might be important contributors to the arthralgias commonly reported by chronic HCV-infected patients $[10,27,28]$.

The differences in the prevalence of joint pain among the three study groups raise important questions for further study. Hypothesized explanations for these findings include differences in unmeasured environmental exposures among the groups or potentially a decrease in local inflammation related to immune dysfunction in HIV infection, resulting in a decreased effect of chronic $\mathrm{HCV}$ in the HIV/HCV-coinfected patients $[29,30]$ Additionally, HIV-infected patients may be more tolerant of joint discomfort due to higher priority placed on more serious complications of their underlying disease. In general, HCV-infected patients with joint pain had a high prevalence of self-reported depression, anxiety, and sleep disturbance. Depression and anxiety could have contributed to a higher prevalence of joint pain reported by this group since mood and joint pain are strongly linked.

We found that current smoking was strongly associated with joint pain. Smoking has been associated with musculoskeletal pain and the development of rheumatoid arthritis [31] In addition, smoking is associated with worse disease activity in patients with rheumatoid arthritis [32]. However, smoking and its link to joint pain in patients with chronic $\mathrm{HCV}$ has not previously been reported. Importantly, smoking is a modifiable risk factor. Further research is needed to determine whether joint pain in patients with chronic $\mathrm{HCV}$ improves with smoking cessation.

7We found that nearly half of patients with chronic $\mathrm{HCV}$ infection (both HCV-monoinfected and HIV/ HCV-coinfected) and joint pain self-reported 20 or more symptoms which has previously been reported to indicate a fibromyalgia diagnosis [33]. Fibromyalgia has 
Table 2 Multidimensional Health Assessment Questionnaire results among participants reporting joint pain

\begin{tabular}{|c|c|c|c|}
\hline & $\begin{array}{l}\text { HCV/HIV- } \\
\text { Coinfected }\end{array}$ & $\begin{array}{l}\text { HCV- } \\
\text { Monoinfected }\end{array}$ & $\begin{array}{l}\text { HIV- } \\
\text { Monoinfected }\end{array}$ \\
\hline Physical Function Score (Mean(SD)) & $2.4(2.0)$ & $2.6(1.5)$ & $3.3(2.1)$ \\
\hline Pain (Mean(SD)) & $6.5(2.7)$ & $5.6(2.7)$ & $6.2(3.2)$ \\
\hline Patient Global (Mean(SD)) & $3.9(3.3)$ & $4.4(2.4)$ & $4.9(1.7)$ \\
\hline RAPID3 (Mean(SD)) & $12.8(6.3)$ & $12.6(4.9)$ & $14.3(5.6)$ \\
\hline Emotional Score*(Mean(SD)) & $4.2(2.7)$ & $3.7(2.4)$ & $3.7(2.3)$ \\
\hline Total Symptoms (Mean(SD))** & $18.6(10.4)$ & $17.6(9.8)$ & $14.2(10.8)$ \\
\hline Depression, n (\%) & $28(64 \%)$ & $33(50 \%)$ & $12(80 \%)$ \\
\hline Anxiety, n (\%) & $34(77 \%)$ & $34(51 \%)$ & $10(67 \%)$ \\
\hline Sleep Disturbance, n (\%) & $32(73 \%)$ & $41(62 \%)$ & $10(67 \%)$ \\
\hline Dry Eyes, n (\%) & $6(14 \%)$ & $19(29 \%)$ & $0(0 \%)$ \\
\hline Dry Mouth n (\%) & $20(45 \%)$ & $32(48 \%)$ & $3(20 \%)$ \\
\hline Numbness/tingling n (\%) & $18(41 \%)$ & $18(27 \%)$ & $1(7 \%)$ \\
\hline Myalgias, n (\%) & $19(43 \%)$ & $17(26 \%)$ & $1(7 \%)$ \\
\hline Morning Stiffness, n (\%) & $29(66 \%)$ & $44(67 \%)$ & $8(53 \%)$ \\
\hline Fatigue Scale (Mean(SD)) & $4.53(3.68)$ & $4.73(3.44)$ & $3.97(3.82)$ \\
\hline$\geq 20$ Symptoms Reported & $42(45 \%)$ & 43 (54\%) & $7(23 \%)$ \\
\hline
\end{tabular}

Only patients reporting joint pain completed the MD-HAQ. *The MD-HAQ includes an emotional function assessment in which depression, anxiety and sleep disturbance each ranked as none (0), mild (1.1), moderate (2.2) or severe (3.3). The total "emotional score" is the combined sum of these three components (range 0-9.9).

**The MD-HAQ contains a 60-item review of systems (including depression, anxiety, sleep disturbance, dry eyes, dry mouth, numbness/tingling, myalgias, and morning stiffness. There is additionally a visual analog scale for fatigue.

been reported to be common among patients with chronic HCV although the reason for this association is unclear $[27,28]$.

Our study was limited by its cross-sectional design, use of convenience sampling, our inability to perform physical examinations and obtain imaging studies to rule out osteoarthritis, and the relatively small sample. In particular, there is the possibility that patients with joint pain may have been more likely to complete the survey. Additionally, we were unable to determine the specific etiologies for the joint pain. While many patients reported a diagnosis of arthritis, we did not confirm these diagnoses on physical examination or further testing. Furthermore, some patients were prescribed analgesic medications, and these patients might have less commonly self-reported joint pain. Finally, our study evaluated patient-reported joint complaints present within the one week prior to the survey date. Thus, there may have been patients with intermittent joint pain who were not identified in this study. However, use of the one week time frame limits the risk of recall bias and is the time period specified on the MD-HAQ for assessment of disease activity in rheumatoid arthritis.

Table 3 Factors associated with joint pain in chronic hepatitis C virus-infected and human immunodeficiency virus-infected participants

\begin{tabular}{|c|c|c|c|c|}
\hline & \multicolumn{2}{|l|}{$\mathrm{HCV}$} & \multicolumn{2}{|l|}{ HIV } \\
\hline & Univariable models (Unadjusted) & Multivariable model & Univariable models (Unadjusted) & Final model \\
\hline & OR $(95 \% \mathrm{Cl})$ & OR $(95 \% \mathrm{Cl})$ & OR $(95 \% \mathrm{Cl})$ & OR $(95 \% \mathrm{Cl})$ \\
\hline Co-infection & $0.51(0.27-0.97)$ & $0.49(0.23-1.05)$ & $1.26(0.54-2.92)$ & \\
\hline Age (cont) & $1.01(0.96-1.06)$ & & $0.97(0.91-1.03)$ & \\
\hline Female Sex* & $0.95(0.41-2.23)$ & & $1.41(0.43-4.63)$ & \\
\hline Current Smoker & $3.50(1.71-7.18)$ & $5.02(2.15-11.74)$ & $5.43(2.18-13.52)$ & $6.07(2.30-16.00)$ \\
\hline Obesity (BMI > 30) & $1.85(0.90-3.79)$ & $1.29(0.57-2.92)$ & $1.70(0.68-4.29)$ & \\
\hline Previous Diagnosis of Arthritist & $4.47(2.11-9.48)$ & $4.25(1.84-9.81)$ & $4,74(1.90-11.81)$ & $5.36(2.01-14.25)$ \\
\hline
\end{tabular}

*Males are the referent group. †Previous arthritis diagnosis included rheumatoid arthritis $(\mathrm{N}=4)$, ankylosing spondylitis ( $\mathrm{N}=1$ ), systemic lupus erythematosus $(\mathrm{N}=1)$, osteoarthritis $(\mathrm{N}=46)$, and patient reported "arthritis" but unknown type $(\mathrm{N}=22)$. Abbreviations: $\mathrm{BMI}=$ body mass index. 


\section{Conclusions}

Among patients with HIV and/or chronic HCV infections, joint pain was prevalent. HCV-monoinfected patients more frequently reported arthralgias compared to $\mathrm{HIV} / \mathrm{HCV}$-coinfected or HIV-monoinfected persons. These results suggest that joint pain remains a major health concern and a determinant of health-related quality of life among these patients. Providers should seek to address modifiable risk factors for joint pain (e.g., smoking cessation) in such persons. Future studies should determine the etiologies and strategies for management of joint pain, including fibromyalgia, in patients with chronic HCV and HIV infection, as well as the mechanisms for modulation of joint symptoms in $\mathrm{HIV} / \mathrm{HCV}$ coinfected patients.

\section{Additional file}

Additional file 1: Table S1. Laboratory results of human immunodeficiency virus (HIV)/chronic hepatitis C virus (HCV)-coinfected chronic HCV-monoinfected, and HIV-monoinfected participants.

\section{Abbreviations}

ALT: Alanine aminotransferase; AST: Asparate aminotransferase; BMI: Body mass index; HCV: Hepatitis C Virus; HIV: Human Immunodeficiency Virus; HUP: Hospital of the University of Pennsylvania; INR: International normalized ratio; IQR: Interquartile range; MD-HAQ: Multi-Dimensional Health Assessment Questionnaire; NSAID: Non-steroidal anti-inflammatory drug; PPMC: Penn Presbyterian Medical Center; PVAMC: Philadelphia Veterans Affairs Medical Center; RAPID3: Routine Assessment of Patient Index Data; RNA: Ribonucleic acid.

\section{Competing interests}

The authors declare that they have no competing interests.

\section{Authors' contributions}

$A O, V L$, and $H R S$ conceptualized and designed the study with help from $K M$, $V A$, JK, and DE. All contributed substantially to data acquisition. AO, VL, HRS, WGP, KM, KAF, JK, SDB, LM, and KRR assisted in interpretation of the data. AO performed the statistical analysis with assistance from $V L$ and KAF. AO and WGP together drafted the first version of the manuscript. All authors were involved in revision of the manuscript and all approved the final version.

\section{Acknowledgements \\ We would like to thank Janet Dinella and Yihui Connie Jiang for administrative support and Melissa Nezamzadeh for assistance with database management. This study was funded by the American College of Rheumatology Research Foundation Ephram Engleman Preceptorship Award. During this study, Dr. Ogdie was supported by an American College of Rheumatology Research Foundation Investigator Award and research grant K23 AR063764 from the National Institute of Arthritis and Musculoskeletal and Skin Diseases, and Dr. Lo Re was supported by research grant K01 Al 070001 from the National Institute of Allergy and Infectious Diseases.}

\section{Previous presentations}

This project was presented as a poster at the American College of Rheumatology Annual Conference in Washington, DC in 2012.

\section{Author details}

'Division of Rheumatology, Center for Clinical Epidemiology and Biostatistics, Perelman School of Medicine at the University of Pennsylvania, Penn Tower Room 1407, 1 Convention Ave, Philadelphia PA 19104, USA. ${ }^{2}$ Maine Medical Center, Tufts University School of Medicine, Portland, ME, USA. ${ }^{3}$ Department of Medicine, Division of Gastroenterology, Center for Clinical Epidemiology and Biostatistics, Perelman School of Medicine at the University of
Pennsylvania, Philadelphia, PA, USA. ${ }^{4}$ Seacoast Arthritis and Osteoporosis Center, 10 Members Way, Suite 403, Dover NH 03820, USA. ${ }^{5}$ Perelman School of Medicine, the University of Pennsylvania, Philadelphia, PA, USA. ${ }^{6}$ Division of Gastroenterology, Philadelphia VA Medical Center, Perelman School of Medicine at the University of Pennsylvania, Philadelphia, PA, USA. ${ }^{\text {Division of }}$ Infectious Diseases, Philadelphia VA Medical Center, Perelman School of Medicine at the University of Pennsylvania, Philadelphia, PA, USA. ${ }^{8}$ Division of Gastroenterology, Perelman School of Medicine at the University of Pennsylvania, Philadelphia, USA. ${ }^{9}$ Division of Rheumatology, Philadelphia VA Medical Center, Perelman School of Medicine at the University of Pennsylvania, Philadelphia, PA, USA. ${ }^{10}$ Department of Medicine, Division of Infectious Diseases, Center for Clinical Epidemiology and Biostatistics, Perelman School of Medicine at the University of Pennsylvania, Philadelphia, PA, USA.

Received: 25 September 2014 Accepted: 13 April 2015

Published online: 19 April 2015

\section{References}

1. Mohd Hanafiah K, Groeger J, Flaxman A, Wiersma S. Global epidemiology of hepatitis C virus infection: new estimates of age-specific antibody to HCV seroprevalence. Hepatology. 2013;57(4):1333-42.

2. Armstrong G, Wasley A, Simard E, McQuillan G, Kuhnert W, Alter M. The prevalence of hepatitis C virus infection in the United States, 1999 through 2002. Annals Int Med. 2006;114(10):705-14

3. Ko H, Hernandez-Prera J, Zhu H, Dikman SH, Sidhu HK, Ward SC, et al. Morphologic features of extrahepatic manifestations of hepatitis $C$ virus infection. Clin Dev Immunol. 2012;2012:740138.

4. Lang C, Conrad S, Garrett L, Battistutta D, Cooksley W, Dunne M, et al. Symptom prevalence and clustering of symptoms in people living with chronic Hepatitis C infection. J Pain Symp Man. 2006;31(4):335-44.

5. Becker J, Winthrop L. Update on rheumatic manifestations of infectious diseases. Cur Op Rheumatology. 2010;22:72-7.

6. Himoto T, Masaki T: Extrahepatic manifestations and autoantibodies in patients with hepatitis $C$ virus infection. Clin Dev Immunol 2012, 2012(871401).

7. Zhaojing C, Baotong Z, Xiaochun S, Yao Z, Lifan Z, Limeng C, et al. Extrahepatic manifestations of chronic hepatitis C virus infection: 297 cases from a tertiary medical center in Beijing. China Chin Med J. 2014;127(7):1206-10.

8. Calvaruso V, Craxi A. Immunological alternations in hepatitis $C$ virus infection. World J Gastroenterol. 2013;19(4):8916-23.

9. Palazzi C, D'Amico E, D'Angelo S, Gilio M, Leccese P, Olivieri I. An update on the management of hepatitis $C$ virus-related arthritis. Expert Opin Pharmacother. 2014;15(14):1-7.

10. Sayiner ZA, Haque U, Malik MU, Gurakar A. Hepatitis C virus infection and its rheumatologic implications. Gastroenterol Hepatol. 2014;10(5):287-93.

11. Zampino R, Marrone A, Restivo L, Guerrera B, Sellitto A, Rinaldi L, et al. Chronic HCV infection and inflammation: Clinical impact on hepatic and extra-hepatic manifestations. World J Hepatol. 2013;5(10):528-40.

12. Lawson $\mathrm{E}$, Walker-Bone $\mathrm{K}$. The changing spectrum of rheumatic disease in HIV infection. Br Med Bull. 2012;103(1):203-21.

13. Kim A, Wiesch J, Kuntzen T, Timm J, Kaufmann D, Duncan J, et al. Impaired hepatitis $C$ virus-specific $T$ cell responses and recurrent hepatitis $C$ virus in HIV. Coinfection. 2006;3(12), e492.

14. Koziel M. Influence of HIV co-infection on hepatitis C immunopathogenesis. J Hepatol. 2006;44(1 Suppl):S14-8.

15. Lo Re V, Kallan MJ, Tate JP, Localio AR, Lim JK, Goetz MB, et al. Hepatic decompensation in Antiretroviral-treated HIV/Hepatitis C-coinfected compared to Hepatitis C-monoinfected patients: A cohort study. Ann Intern Med. 2014;160(6):369-79.

16. The MDHAQ-RAPID3. [http://www.mdhaq.org/]

17. Pincus T, Swearingen CJ, Bergman M, Yazici Y. RAPID3 (Routine Assessment of Patient Index Data 3), a rheumatoid arthritis index without formal joint counts for routine care: proposed severity categories compared to disease activity score and clinical disease activity index categories. J Rheumatol. 2008;35(11):2136-47.

18. Pincus T, Sokka T, Kautianinen H. Further development of a physical function scale on a MDHAQ for standard care of patients with rheumatic diseases. J Rheumatol. 2005;32(8):1432-9. 
19. Pincus T, Yazici Y, Sokka T. Quantitative measures of rheumatic diseases for clinical research versus standard clinical care: differences, advantages, and limitations. Best Prac Res Clin Rheumatol. 2007;21 (4):601-28.

20. Pincus T, Sokka T. Can a Multi-Dimensional Health Assessment Questionnaire (MDHAQ) and Routine Assessment of Patient Index Data (RAPID) scores be informative in patients with all rheumatic diseases? Best Pract Res Clin Rheumatol. 2007;21 (4):733-53.

21. Pincus T, Yazici Y, Castrejón I. Pragmatic and scientific advantages of MDHAQ/RAPID3 completion by all patients at all visits in routine clinical care. Bull NYU Hosp Jt Dis. 2012;70 Suppl 1:30-6.

22. Pincus T, Askanase A, Swearingen C. A multi-dimensional health assessment questionnaire (MDHAQ) and routine assessment ofpatient index data (RAPID3) scores are informative in patients with all rheumatic diseases. Rheum Dis Clin North Am. 2009;35(4):819-27.

23. Barkhuizen A, ROsen H, Wolf S, Flora K, Benner K, Bennett R. Musculoskeletal pain and fatigue are associated with chronic hepatitis C A Srep 239. Hepatology Clin Pat . 1999:94(5):1355-60.

24. Banks S, Riley T, Naides S. Muscculoskeletal complaints and serum autoantibodies associated with chronic Hepatitis $\mathrm{C}$ and Nonalcoholic Fatty liver disease. Dig Dis Sci. 2007;52:1117-82.

25. Tsui J, Cheng D, Libman H, Bridden C, Samet J. Hepatitis C virus infection is associated with painful symptoms in HIV-infected adults. AIDS Care. 2012;24(7):820-7.

26. Cacoub P, Renou C, Rosenthal E, Cohen P, Loury I, Loustaud-Ratti V, et al. Extrahepatic manifestations associated with hepatitis $C$ virus infection. Medicine. 2000;79(1):47-55.

27. Rogal S, Bielefeldt K, Wasan A, Szigethy E, Lotrich F, DiMartini A: Fibromyalgia Symptoms and Cirrhosis. Dig Dis Sci 2014 Nov, [Epub ahead of print]

28. Mohammad A, Carey J, Storan E, Scarry M, Coughlan R, Lee J. Prevalence of fibromyalgia among patients with chronic hepatitis $\mathrm{C}$ infection: relationship to viralcharacteristics and quality of life. J Clin Gastroenterol. 2012;46(5):407-12.

29. Rotman $Y$, Liang $T$. Coinfection with hepatitis $C$ virus and human immunodeficiency virus: virological, immunological, and clinical outcomes. J Virol. 2009:83(15):7366-74

30. Kim A, Wiesch J, Kuntzen T, Timm J, Kaufmann DE, Duncan JE, et al. Impaired hepatitis C virus-specific T cell responses and recurrent hepatitis $C$ virus in HIV Coinfection. PLoS Med. 2006;3((12):e492.

31. Abate M, Vanni D, Pantalone A, Salini V. Cigarette smoking and musculoskeletal disorders. Mus Liga Tend J. 2013;3(2):63-9.

32. Lu B, Rho YH, Cui. J., lannaccone. C.K., Frits ML, Karlson EW, Shadick NA: Associations of Smoking and Alcohol Consumption with Disease Activity and Functional Status in Rheumatoid Arthritis. J Rheumatol 2013, Epub.

33. Pincus T, Hassett A, Callahan L. Clues on the MDHAQ to identify patients with fibromyalgia and similar chronic pain conditions. Rheum Dis Clin North Am. 2009;35(4):865-9.

\section{Submit your next manuscript to BioMed Central and take full advantage of:}

- Convenient online submission

- Thorough peer review

- No space constraints or color figure charges

- Immediate publication on acceptance

- Inclusion in PubMed, CAS, Scopus and Google Scholar

- Research which is freely available for redistribution 